\title{
OBJETOS E INFLUJOS DE FLANDES EN LA CULTURA MATERIAL EN LA CIUDAD DE MALLORCA, SIGLO XV ${ }^{1}$
}

\section{MIQUEL ÀNGEL CAPELLÀ GALMÉS}

UDC: $7.075: 745 / 749(48: 460.32) " 14 "$

Review

Manuscript received: 02. 11. 2015.

Revised manuscript accepted: 30. 03. 2016.

DOI: 10.1484/J.HAM.5.111357

\author{
M. À. Capellà Galmés \\ Universitat de les Illes Balears \\ Dept. de Ciències Històriques i Teoria de les Arts \\ Cra. de Valldemossa, km. 7.5 \\ 07122 Palma (Spain) \\ ma.capella@uib.es
}

The harbor of Palma, due to its geographical position, constitutes an inevitable crossroads in the trading routes connecting Italy and Flanders. The main purpose of this article is to study the influence and the presence of Flemish and Nordic productions of decorative arts in the island through trade. The research is based on the few remaining documents written at the time, which barely represent a part of the volume of this commercial traffic. A considerable number of these artistic objects are the result of standardized means of production linked to the prosperity of the markets and the increase of marketable goods occurred in this period of the Late Middle Ages. These works could be purchased by merchants during their trips to fairs or urban workshops, some were the result of serial production, maybe purchased at a relatively economic price, despite maritime transportation, and destined to affording customers, though anonymous a priori.

Keywords: artistic exchange, probate inventories, material culture, brass, bronze, tapestries.

La cultura material acumulada en las casas de la Ciudad de Mallorca en la baja edad media es, en buena parte, el reflejo del intenso tráfico comercial de su puerto ${ }^{2}$. Gracias a su situación geográfica, en la isla confluían las principales rutas comerciales mediterráneas, en concreto aquellas que conectaban las ciudades del norte de Italia con la zona de Flandes y la corte de Borgoña ${ }^{3}$, los dos polos económicos-culturales más dinámicos en este período. Esta encrucijada marítima establecida ya desde el siglo XIV4, contribuyó a la presencia de mercaderes y emisarios de diferentes territorios europeos, que estaban organizados en más de diez consulados extranjeros, siendo los más destacados el veneciano y el genovés 5 . El comercio fue la base de la economía mallorquina y la constitución del Colegio de la Mercadería, con la posibilidad de cobrar por las "mercancías que entraban o salían del puerto" ${ }^{6}$, permitió la construcción de la Lonja encargada a Guillem Sagrera en $1416^{7}$, un edificio que simbolizó el poder económico del estamento mercader y un exponente de la arquitectura civil mediterránea de primer orden ${ }^{8}$.

La decoración interior de las casas de la oligarquía mallorquina -caballeros, ciudadanos y mercaderes- como ha estudiado la Dra. Barceló basándose en la documentación notarial9, refleja este ambiente cosmopolita ligado al puertoy la extraordinaria circulación de objetos. Estos se combinaron en un mismo ámbito espacial privado, que podemos definir como caleidoscópico, ya que es múltiple y cambiante, porque en él se usaron y disfrutaron piezas de artes suntuarias elaboradas en lugares tan dispares como Alejandría, Flandes o Venecia ${ }^{10}$. El deseo de lo exótico, la difusión de las modas de las cortes y los cambios en los modelos de producción

\footnotetext{
${ }^{1}$ Esta aportación forma parte de la transferencia de conocimientos del proyecto de investigación Ciudades históricas y paisaje construido en Mallorca (HAR2012-36193), financiado por el Ministerio de Economía y Competitividad, Gobierno de España.

${ }^{2}$ Las rutas marítimas están bien estudiadas. La primera «procedía de Oriente, básicamente seguida por los comerciantes de las ciudades-repúblicas italianas, que pasando por Menorca y Mallorca, se dirigía hacia el estrecho de Gibraltar, haciendo posible escala en Almería o Málaga, recalando en Lisboa y puertos de Galicia, para concluir en el Mar del Norte. Era la ruta llamada a poner en comunicación el Este con el Oeste; en otras palabras, Flandes, Inglaterra y los países del Hansa con el Oriente mediterráneo. La segunda ruta, que también cruzaba las Baleares, lo hacía de norte a sur y viceversa. Era la que trataba de unir los puertos africanos de Berbería -Salé, Larache, Ceuta, Arxila, Mazagrán, Argel, Orán, Constantina, Bugía, Túnez- haciendo escala en las islas, para luego alcanzar Cotlliure, Perpiñán, Tolosa y llanuras de Aquitania, con destino final en París y Flandes», R. PIÑA HOMS, El Consolat de Mar, Mallorca, 1326-180o, Palma, 1985, p. 32.

3 W. PARAVICINI (ed.), La cour de Bourgogne et l'Europe. Le rayonnement et les limites d'un modèle culturel, Ostfildern, 2013.

${ }^{4}$ Las principales investigaciones que recogen este tráfico comercial en el siglo comercial son las de F. SEVILLANO COLOM, De Venecia a Flandes (Vía Mallorca y Portugal, siglo XIV), in BSAL 23, 1968, p. 1-33; D. ABULAFIA, Un emporio mediterráneo: el reino catalán de Mallorca, Barcelona, 1996 y, recientemente, A. ORTEGA VILLOSLADA, El reino de Mallorca y el mundo atlántico, 1230-1349: evolución político-mercantil, A Coruña, 2008. Para el siglo XV, son fundamentales los datos recogidos en O. VAQUER BENNASAR, El comerç marítim de Mallorca 1448-1531, Mallorca, 2001.

${ }^{5}$ M. BARCELÓ CRESPÍ, G. ROSSELLÓ BORDOY, La Ciudad de Mallorca. La vida cotidiana en una ciudad mediterránea medieval, Palma, 2006, p. 399.

${ }^{6}$ M. M. RIERA FRAU, El Colegio de la Mercadería, in F. CLIMENT GUIMERÀ (coord.), La lonja de Palma, Palma, 2003, p. 35.

7 G. ALOMAR I ESTEVE, Guillem Sagrera y la arquitectura gótica del siglo XV, Barcelona, 1970.

${ }^{8}$ F. CLIMENT (coord.), La lonja de Palma, Palma, 2003.

${ }^{9}$ M. BARCELÓ CRESPÍ, Elements materials de la vida quotidiana a la Mallorca Baixmedieval (Part Forana), Palma, 1994. Véase también: J. SASTRE MOLL, Alguns aspectes de la vida quotidiana a la Ciutat de Mallorca (Època Medieval), Palma, 1997.

${ }^{10} \mathrm{M}$. À. CAPELLÀ GALMÉS, Las artes suntuarias en el reino de Mallorca en la segunda mitad del s. XV: mercados, clientes y gusto artístico, in Anales de Historia del Arte 24, 2014, p. 53-67.
} 


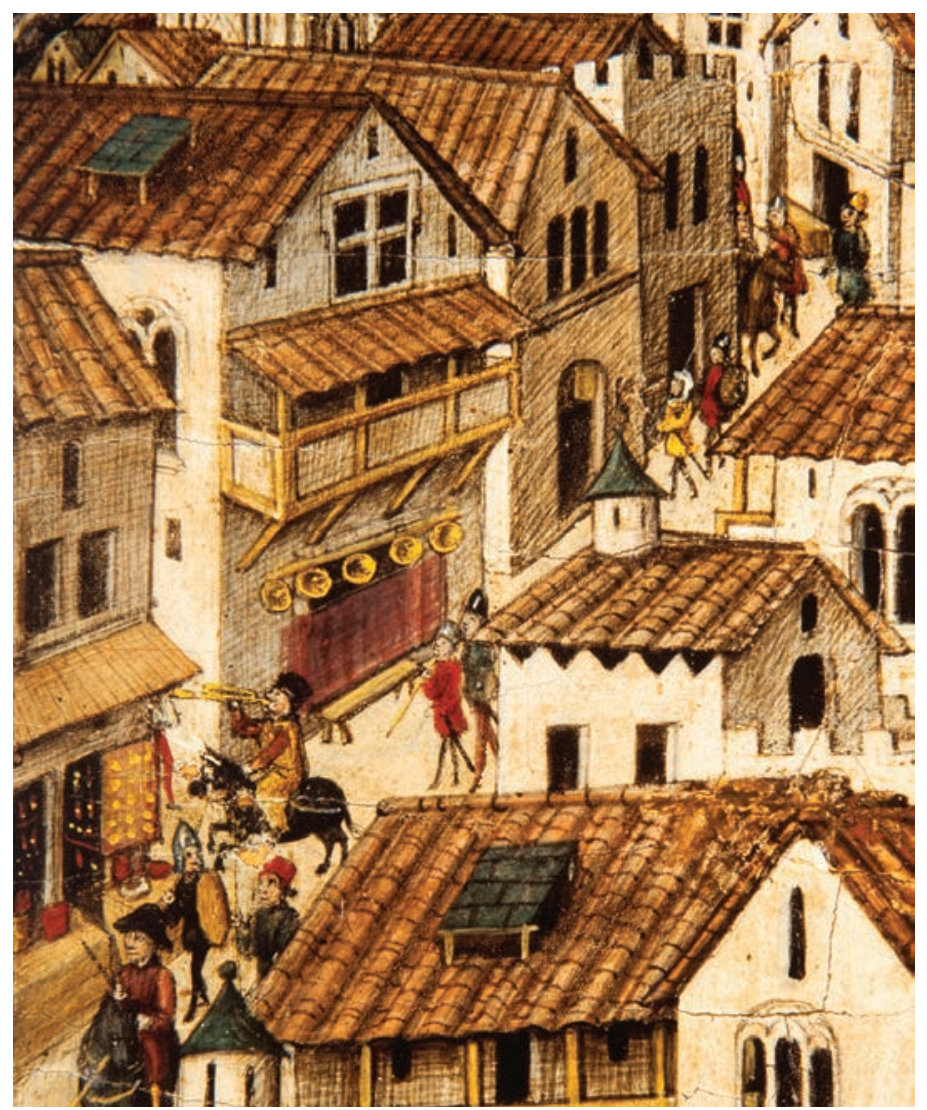

Fig. 1. Detalle de una calle comercial representada en el retablo de San Jorge de Pere Niçard, 1468-70, Museo Diocesano de Mallorca (Palma). Fot.: J. Gual

provocaron en este final de la edad media una multiplicación de los objetos artísticos, tanto religiosos como profanos, en el interior de las viviendas ${ }^{11}$. Basta revisar el inventario redactado en 1465 de la casa del tendero Pere Ylari ${ }^{12}$, situada en la plaza de la Cort de la Ciudad de Mallorca, centro administrativo de la ciudad, para darse cuenta del catálogo de cosas accesible a sus clientes (fig. 1). Del análisis del contenido de su establecimiento, se deduce una cierta especialización en productos textiles de toda índole, dentro de una gran diversidad de materias. La geolocalización realizada por el notario deja clara esta variedad: Bristol (Inglaterra), Ostende y Borgoña (Países Bajos), Calabria, Génova, Mesina, Nápoles (Italia), Alemania y Alejandría (Egipto).
El principal objetivo de este artículo es el estudio de los objetos de artes decorativas -madera, vidrio, metal y tapicesprocedentes de Flandes y del norte de Europa documentados en las casas de la Ciudad de Mallorca. Nos basamos en las fuentes escritas de la época y en los pocos ejemplares que nos permiten concretar una materialidad perdida. En otros casos por analogía, hemos recurrido a representaciones pictóricas o a paralelos conservados en diferentes colecciones europeas y americanas. La influencia del mundo flamenco en la pintura y la escultura ha sido sistematizada y tratada ampliamente en diversas publicaciones ${ }^{13}$, en cambio, el mundo del objeto ha sido menos trabajado al no haber generado transformaciones significativas en la producción local ${ }^{14}$. De hecho, el impacto en la Corona de Aragón fue mucho menor que el provocado en la de Castilla ${ }^{15}$.

\section{LOS MERCADERES MALLORQUINES Y FLANDES}

Las galeras genovesas y venecianas que navegaban a Flandes hacían escala en Mallorca, lo que les permitía incorporar en sus fletes productos norteafricanos y de otras procedencias $^{16}$. En 1459 el importante mercader Jordi Pont ${ }^{17}$ viajó en una de estas flotas que se dirigían a Brujas ${ }^{18}$, puerto de acceso a los Países Bajos. Estuvo en la ciudad durante cuatro meses realizando diversas actividades económicas y se trasladó también a Amberes. Entre sus cuentas se detallan varias compras de ropa al detalle y alguna al por mayor, que seguro que no fueron las únicas de su viaje, como por ejemplo las 500 agujas que adquirió, probablemente destinadas a la confección de togas y otros complementos de la indumentaria femenina. Debió relacionarse con el resto de la comunidad de comerciantes de la Corona de Aragón, que estaban constituidos en consulado desde $1330^{19}$, y entró en contacto con las peculiaridades de los interiores de las casas en los países bajos borgoñones y probablemente se fijó en aspectos de la decoración que las diferenciaban de los interiores insulares.

¿Podemos hablar con propiedad de un interior flamenco burgués, que pudiese ser objeto de atención por parte de los mercaderes mallorquines en su estancia en la ciudad de Brujas o es una construcción historiográfica? ${ }^{20}$. Si analizamos las habitaciones representadas en la pintura religiosa sobre tabla desde el siglo XVy hasta inicios de la centuria siguiente,

\footnotetext{
"J. V. GARCÍA MARSILLA, Imatges a la llar. Cultura material i cultura visual a la València dels segles XIVi XV, in Recerques 43, 2001, p. 163-194.

${ }^{12}$ M. A. SEGURA BONNÍN, M. BARCELÓ CRESPÍ, Inventari del botiguer Pere Ylari (1465), in BSAL 69, 2013, p. 289-309. Del mismo período tan sólo se conocen otros dos inventarios de tiendas situadas fuera de la ciudad, véase: G. LLOMPART, Botiguers i quincallaires a la pagesia de la Mallorca medieval, in $B S A L$ 52, 1996, p. 179-208. El estudio de inventarios de más tiendas permitirá en un futuro próximo conocer con mucho más detalle las características del mercado, el aprovisionamiento de materias y de bienes de lujo. En este sentido, una buena muestra del trabajo con los mercados y los consumidores, es el inspirador texto de E. WELCH, De compras en el Renacimiento: culturas del consumo en Italia, 1400-1600, València, 2009.

${ }_{13}$ Véase T. SABATER, La pintura mallorquina del segle XV, Palma, 2002, p. 321.

${ }^{14}$ El marco general definido y la catalogación de objetos son de gran interés para un mayor conocimiento de estas transferencias véase: G. LLOMPART, Mallorca, cap de creus, in Mallorca Gòtica, Palma, 1998, p. 13-20; G. LLOMPART MORAGUES, Mallorca-Flandes: Línia directa i costa amunt, in F. RUIZ QUESADA, A. GALILEA ANTON (ed.), La pintura gòtica hispano flamenca. Bartolomé Bermejo i la seva època, Barcelona, 2003, p. 69-75.

${ }^{15} \mathrm{~J}$. YARZA, El arte de los Países Bajos en la España de los Reyes Católicos, in Reyes y Mecenas. Los Reyes Católicos-Maximiliano I y los inicios de la Casa de Austria en España, Toledo, 1992, p. 133-150.

${ }^{16}$ Un panorama general de las materias primas, los productos exportados desde el Mediterráneo, así como la riqueza de conexiones establecidas entre el triángulo Mallorca-Valencia-Barcelona se puede leer en M. T. FERRER, El comerç català a la baixa edat mitjana, in Catalan Historical Review 5, 2012, p. 159-193. ${ }^{17}$ Estaba casado con Agnès, hija de Pere Espanyol, también mercader que había ascendido a ciudadano. Véase M. BARCELÓ CRESPÍ, B. COLL TOMÀS, G. ROSSELLÓ BORDOY, Espanyols i Pacs: poder i cultura a la Mallorca del segle XV, Palma, 1999, p. 34-35.

${ }^{18}$ J. RAMIS DE AYREFLOR, Mercaderes mallorquines del siglo XV. Partidas curiosas de los libros de cuentas de la familia Pont, in BSAL 20, 1924-1925, p. 274-276, 298-300, 315-317, 336-338, 374-375.

${ }^{19}$ D. PIFARRÉ I TORRES, El comerç internacional de Barcelona i el mar del Nord (Bruges) a finals del segle XIV, Barcelona, 2002; P. DESPORTES BIELSA, El consulado catalán de Brujas (1330-1488), in Aragón en la Edad Media 14-15, 1999, p. 375-390.

${ }^{20}$ M. PRAZ, Historia ilustrada de la decoración. Los interiores desde Pompeya hasta el siglo XVIII, Barcelona, 1965, p. 8o-81.
} 
podemos ver cómo determinados objetos se van repitiendo en las pinturas. Aunque no consta ningún contrato entre patrono y pintor, en el que se le explicite la representación de un interior privado concreto, sí que se especifica en alguna obra el deseo de que se pintase el mobiliario y las cosas que distinguían los ambientes de los "seigneurs et bourgois"21. Esta iconografía doméstica está dispuesta de forma meticulosa por el pintor y probablemente se trata de un conjunto estereotipado, que ha seleccionado cuidadosamente uniendo detalles de diferentes ambientes. La escuela pictórica describió con gran detalle y veracidad estos bienes materiales, que parece que definían el interior burgués borgoñón, que se pretendía diferente del nobiliario ${ }^{22}$.

Brujas, fue el gran centro de redistribución de las mercancías y objetos de lujo en el norte de Europa, lugar de confluencia de la zona germánica y la hanseática. El castellano Pero Tafur en sus Andanzas e viajes de un hidalgo español (1435-1489), describió esta ciudad, como un crisol, donde se vendían bienes procedentes del Brabante, Picardía o Alemania ${ }^{23}$. En toda la región el desarrollo de las ferias y los mercados semanales, en ocasiones especializados por productos artísticos ${ }^{24}$, debió suponer también un estímulo añadido para la estandarización de determinadas producciones. Además, se produjo una reconversión de la industria urbana hacia los oficios artísticos y los artefactos de lujo ${ }^{25}$, una reestructuración sostenida por las demandas de las clases privilegiadas borgoñonas. En especial, en las artes del objeto, al modo de producción convencional de la vía del encargo a un artista-artesano de reconocido prestigio se le sumó la ejecución estandarizada o la elaboración en serie ${ }^{26}$. Estas mercancías artísticas producidas en serie y no como resultado de un encargo concreto, presentaban las ventajas de su disponibilidad inmediata y unos precios razonables ${ }^{27}$. El mercader y sus representantes en la zona conocían las novedades y aquellas pequeñas obras que tenían éxito, con facilidad año tras año eran transferidas a sus territorios de origen. Esta práctica del comercio ha quedado recopilada, al menos parcialmente, en los manuales comerciales, en los que se racionalizaba la actividad comercial y se buscaba la máxima rentabilidad ${ }^{28}$.

\section{LAS VIDRIERAS}

En algunos de los interiores representados en la pintura de Flandes llama la atención la presencia de vidrieras, de reducidas dimensiones, aplicadas en la parte superior de ventanas en cruz o de otra tipología, que en la inferior tenían postigos de madera como cerramiento ${ }^{29}$. Este tipo de vitrales, destinados por sus reducidas dimensiones preferentemente a interiores privados, pueden detectarse en la documentación escrita insular ${ }^{30}$. Así, el caballero Joan de Dameto en 1477 tenía una de cinco palmos de largo y tres de ancho, en la que se había representado a la Virgen y otros santos, que estaba rota y retirada en el porche de su casa $^{31}$. Las dimensiones evidencian de manera clara que se trataba de un objeto destinado a las salas de la arquitectura privada y no a la eclesiástica. Un caso similar era la que tenía el notario Pere Moranta en 1499, con idéntica iconografía y de la misma procedencia ${ }^{32}$.

Una prueba que a finales del siglo XV no existía en Mallorca ningún taller especializado en la realización de vitrales con calidad pictórica la tenemos en la compra de seis vidrieras en 1505 en Montpellier por parte del prior de la Cartuja de Valldemossa. Estaban destinadas al refectorio y gracias a fotografías antiguas se deduce que eran de origen flamenco. La única vidriera conservada a fines del siglo XIX (fig. 2), posteriormente vendida y hoy en paradero desconocido33, era de 77 por $58 \mathrm{~cm}$ y combinaba elementos vegetales con

\footnotetext{
${ }^{21}$ L. CAMPBELL, The Art Market in the Southern Netherlands in the Fifteenth Century, in Burlington Magazine 118, 1976, p. 192-193.

${ }^{22}$ C. HARBISON, El espejo del artista. El arte del Renacimiento septentrional en su contexto histórico, Madrid, 2007, p. $27-28$.

${ }^{23}$ O. PÉREZ MONZÓN, Producción artística en la Baja Edad Media. Originalidad y/o copia, in Anales de Historia del Arte 22, 2012 , p. 95.

${ }^{24}$ La aproximación al estudio de los mercados artísticos supone un punto de vista nuevo, que ayuda al estudio de la difusión de las obras de arte y a las conexiones entre las diferentes regiones europeas. Véase, entre otros, M. P. J. MARTENS, Some Aspects of the Origins of the Art Market in Fifteenth-Century Bruges, in M. NORTH, D. ORMROD (ed.), Markets for art, 1400-18oo, Sevilla, 1998, p. 19-27; P. SPUFFORD, Power and Profit. The Merchant in Medieval Europe, London, 2002, p. 228-285 o la reciente obra coordinada por S. BROUQUET, J. V. GARCÍA MARSILLA (ed.), Mercados del lujo, mercados del arte. El gusto de las elites mediterráneas en los siglos XIV y XV, València, 2015.

${ }_{25}$ R. VAN UYTVEN, Le Grand Heritage, in Les primitifs flamands et leur temps, Lovaina, 1994, p. 15-50.

${ }^{26}$ O. PÉREZ MONZÓN, op. cit. (n. 23), p. 90-91.

${ }^{27}$ M. TOMASI, L'art multiplié: matériaux et problèmes pour une réflexion, in M. TOMASI, S. UTZ (dir.), L'art multiplié production de masse, en série, pour le marché dans les arts entre Moyen Âge et Renaissance, Roma, 2011, p. 7-23.

${ }^{28}$ El mercader Ambrogio di Lorenzo de' Rocchi, representante de la Compagnia Datini, en su libro de cuentas de los años 1394-1395, escrito entre Mallorca y Valencia, anota entre sus cuentas diferentes referencias a los pesos y sistemas comerciales de ciudades como París, Brujas, Londres. En otros casos, se conocen algunas descripciones, como por ejemplo la de un mercader milanés (1517-1519) que deja clara la desviación del comercio de Brujas hacia Amberes, donde «si fano due ferie l'anno, ma quella si fa a la Pentecostte he molto più bella», A. GROHMANN, Fiere e mercati nell'Europa occidentale, Milano, 2011, p. 6-69, 144-147. 29 Un ejemplo son las vidrieras del Díptico de Maarten Nieuwenhove de Hans Memling, obra fechada hacia 1497 (Memlingmuseum, Sint-Janshospitaal, Brujas), en las que el pintor representa la heráldica y el patrón del comitente, pero a la vez, esta obra, nos sirve para identificar diferentes tipologías de vitrales en este interior doméstico unificado, D. DE VOS, Hans Memling. The complete works, London, 1994.

$3^{30}$ Son frecuentes en esta segunda mitad del siglo. Así, por ejemplo el caballero y jurado de la ciudad, Francesc Comelles tenía en 1466 un fragmento pintado con una escena dedicada a San Juan y a San Andrés. Si atendemos al contexto productivo local, aunque no se indique es bastante probable que esta obra también fuese de importación, ya que no existía ningún taller de vitrales, que sepamos (M. À. CAPELLÀ GALMÉS, L’activitat de vitrallers i vidriers de buf a l'arquitectura gòtica. Relacions i influències a la Ciutat de Mallorca, in BSAL 67, 2011, p. 148). En Barcelona incluso se constata la colocación exacta en la estructura arquitectónica de algunas casas (C. DOMÍNGUEZ RODÉS, La vidriera als edificis civils de Catalunya. S. XIV-XVI, in T. CARRERAS, I. DOMÈNECH (ed.), I Jornades Hispàniques d'Història del Vidre. Actes, Barcelona, 2001, p. 305-319).

${ }^{31}$ Item una vedriera obra de Blandes [sic] de larch de cinc pal[m]s e de amplària de III palms, tranquada, en què és pintada Nostra Dona e altres sancts, ARM, Not. C-174, fol. 194-215v.

${ }^{32}$ Hun imatge de vedrieras de obre de Flandes en què és Nostra Dona e diversos sants, ARM, Not. R-987, fol. 46-6o.

33 M. D. C. BOSCH JUAN, La vidriera de la antigua Cartuja de Valldemosa, in Mayurqa 22-2, 1989, p. 687-698. El arquitecto Bartolomé Ferrà en 1887 se preocupó de esta obra y publicó un detalle de algunas de las decoraciones, B. FERRÁ Y PERELLÓ, Vidrios pintados de la Cartuja de Valldemosa, in BSAL 2,1887, p. $24,32$.
} 


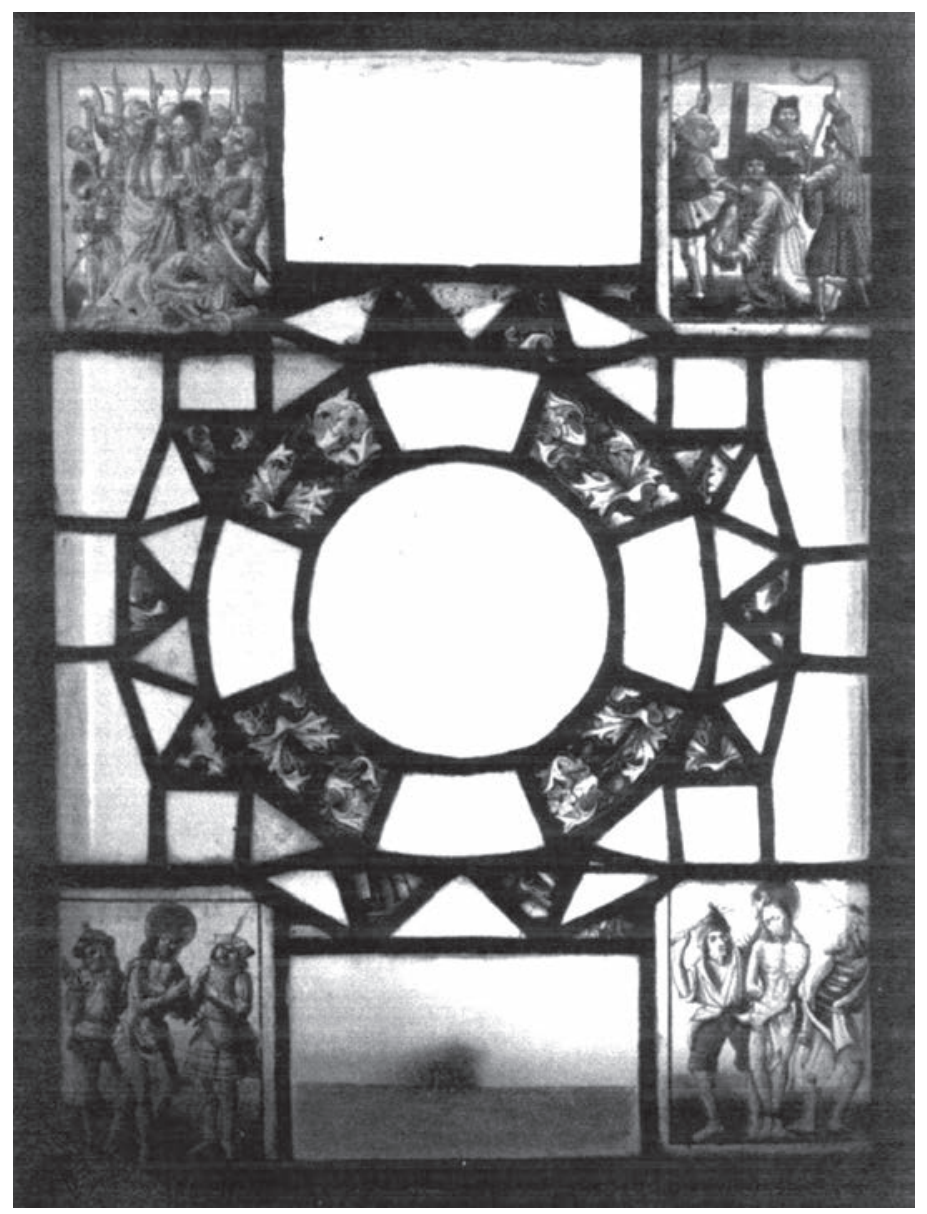

Fig. 2. Vitral de la Pasión, taller flamenco, finales del s. XV. Desaparecido

cuatro paneles rectangulares en los que había escenas de la Pasión de Cristo: el beso de Judas, Cristo portando la cruz, el Ecce Homo y la Flagelación ${ }^{34}$.

\section{EL ROBLE Y EL MOBILIARIO}

La ciudad de Brujas fue un mercado ideal para la compra de madera de calidad como el roble ${ }^{35}$. Una leña dura, pero gratificante de trabajar, ya que aportaba grandes resultados para la realización de decoraciones talladas. La escultura y los retablos realizados en esta materia serán uno de los productos asociados al mercado flamenco de mayor difusión $^{36}$. En 1394 por requerimiento del capítulo de la Catedral de Barcelona, el escultor Pere Sanglada viajó a Brujas para obtener el roble necesario para la construcción y talla del coro catedralicio ${ }^{37}$.

Las referencias a piezas de mobiliario compradas en Flandes o, aunque no podemos constatarlo mediante la documentación, de madera de roble de esa procedencia que se ha trabajado para realizar un mueble concreto en la isla son muy frecuentes en la documentación del siglo XV. Así por ejemplo, Salvador Sureda en 1495 tenía un tinell amb unes polseres o respatlles de roure de Flandes ${ }^{38}$. El tinell era un aparador de lujo propio en las casas de la nobleza y de mercaderes enriquecidos en la Corona de Aragón ${ }^{39}$, que tenía diversos estantes superpuestos y servía para exhibir la vajilla obrada con materias nobles de forma ostentosa ${ }^{40}$.

Si nos centramos en los ejemplares conservados, tan sólo podemos citar la silla de roble de la finca de Alfàbia (Mallorca). Se trata de una butaca de considerables dimensiones que podemos asociar a las numerosas citaciones de los inventarios relativas a diferentes tipos del mobiliario medieval procedentes del norte. Es una pieza excepcional, ya que, como indica el Dr. Llompart ${ }^{41}$, en los albergues de la nobleza tan sólo el señor de la casa disponía de un bien de estas características para poderse sentar, y el resto de los miembros de la familia utilizaban bancos o sillas elaborados con otros materiales y técnicas. Los relieves que la particularizan representan el romance de Tristán e Isolda.

\section{LOS METALES}

Los objetos de producción artesanal realizados en cobre, latón o bronce, de formas estereotipadas con escasas variaciones, se difundieron de forma masiva aprovechando las rutas comerciales marítimas. Estos objetos fueron un elemento de homogeneización artística en Europa por la utilización de modelos similares, la difusión de las obras y la movilidad de los artesanos ${ }^{42}$. La ciudad de Dinant en el Mosa fue el gran centro productor ${ }^{43}$, que adquirió una gran supremacía sobre los demás gracias a las alianzas establecidas con las ciudades de la Hansa y la relación directa con centros comerciales como Brujas o Colonia. Con posterio-

\footnotetext{
$\overline{{ }^{34} \text { C. BAUÇÀ DE MIRABÒ GRALLA, La Real Cartuja de Jesús de Nazaret }}$ de Valldemossa, Palma, 2008, p. 281.

35 O. PÉREZ MONZÓN, op. cit. (n. 23), p. 105.

${ }^{36}$ A. HUYSMANS, La producció de retaules de Brussel-les, Malines i Anvers, in L'esplendor de Flandes. Art de Brussel-les, Anvers i Malines als s. XV-XVI, Barcelona, 1999, p. 27-37.

${ }^{37}$ M. R. TERÉS I TOMÁS, Pere Sanglada i l'arribada del gòtic internacional a Barcelona, in L’Art Gòtic a Catalunya. Escultura II. De la plenitud a les darreres influències foranes, Barcelona, 2007, p. 36-56.

${ }^{38}$ M. BARCELÓ CRESPÍ, Luxe i interior domèstic a la Mallorca dels segles XIV-XV, in S. BROUQUET, J. V. GARCÍA MARSILLA (ed.), Mercados del lujo, mercados del arte. El gusto de las elites mediterráneas en los siglos XIV y XV, València, 2015, p. 330.

39 Aunque se ha documentado algún ejemplar a inicios del siglo XV, incluso anteriores, es en la segunda mitad de esta centuria cuando son más frecuentes. E. PASCUAL I MIRÓ, Els tinells, les taules i els seients, in L’Art Gòtic a Catalunya. Arts de l'Objecte, Barcelona, 2008, p. 320-321; J. MAINAR, El moble català, Barcelona, 1976, p. 44-49. También eran frecuentes en Castilla, O. PÉREZ MONZÓN, Ornado de tapicerías y aparadores de muchas vaxillas de oro y plata. Magnificencia y poder en la arquitectura palatina bajomedieval castellana, in Anales de Historia del Arte 2013, p. 266-267.

$4^{40}$ La literatura coetánea deja bien claro el papel de estos artefactos: «El rey, con todos ellos, entró en la gran sala, e como [la] vio así en orden con todas las viandas prestas y el aparador aparejado de muy rica vaxilla de oro y de plata (...)», J. MARTORELL, Tirant lo Blanch = Tirante el Blanco, València, 2004, vol. 2, p. 50, cap. XXV.

${ }^{41}$ G. LLOMPART MORAGUES, La silla de Alfabia y la materia de Bretaña en la Mallorca de la Baja Edad Media, in Archivo Español de Arte 59, 1986, p. 353362; G. LLOMPART, Anònim. Cadira, in Mallorca Gòtica, Palma, 1998, p. 324-327;

${ }^{42}$ B. PITTARAKIS, Les objets hétéroclites (batterie de cuivre, fonderie), in C. PRIGENT (ed.), Art E société en France au XVe siècle, Paris, 1999 , p. 528.

${ }^{43}$ J. TAVENOR-PERRY, Dinanderie. A History and Description of Mediaeval Art Work in Copper Brass and Bronze, London, 1910; S. COLLON-GEVAERT, Histoire des arts du métal en Belgique, Bruxelles, 1951.
} 
ridad al saqueo de la ciudad en 1466 por Felipe de Borgoña, se produjo una diáspora de artesanos conocedores de las técnicas de la dinanderie hacia otras ciudades como Malinas, Tournai, Namur o Nuremberg.

Estas producciones, en ocasiones de bajo precio y por consiguiente de gran popularidad, eran objeto preferente en los encargos realizados por los mercaderes insulares. En este sentido, vale la pena citar el denominado manual de mercader de Gaspar de Muntaiany44, fechado hacia 1480-1490, donde está anotado que entre los bienes suntuarios importados desde Flandes, los mallorquines apreciaban de manera especial los candelabros y otros objetos de iluminación, los cuencos de latón, aguamaniles y recipientes del servicio de mesa. Estos debían ser objetos preciados en la redecoración de los interiores domésticos y de gran rentabilidad 45 .

Los cuencos y platos de latón, preferentemente, son objetos frecuentes en los inventarios ${ }^{46}$. En 1454 Salvador Mestre, mercader, tenía once bacines de Flandes com Domasquines ${ }^{47}$, es decir imitando las características de las producciones de la ciudad de Damasco. Algunas de ellas eran grandes y estaban destinadas a su exhibición, como la conca gran de lautó per tinell que tenía el procurador real Gregori Burgues en $1505^{48}$.

Los platos limosneros son sin duda el objeto importado que más se ha conservado en las colecciones pertenecientes a instituciones religiosas de Mallorca, aunque no disponemos de un catálogo completo que permita un estudio detallado. La fortuna la deben a su reutilización en muchos casos como bases de lámparas o como platos para recoger limosnas. Los pocos ejemplares catalogados son del siglo XVI, e incluso posteriores, que reproducen decoraciones de modelos góticos, atribuyéndose a talleres de la zona germánica o de Nuremberg. Estas piezas se caracterizan por la variedad iconográfica del centro de la pieza, realizada utilizando moldes y con la técnica de repujado. Las más corrientes en las parroquias mallorquinas tienen los temas de la Virgen y el Niño, la Anunciación, Adán y Eva, San Jorge o Josué y Caleb ${ }^{49}$.

Otra de las tipologías más frecuentes son los productos destinados a la iluminación. El inventario de 1470 de Joan
Bartomeu, ciudadano ${ }^{50}$, nos describe cuatro salomons de leutó de Flandes grans e dos petits ${ }^{11}$. La palabra catalana salamó o salomó, salomonum en latín, documentada ya hacia $1295^{52}$, se utilizaba para designar una araña o candelabro de varios brazos, sin pie, que se colgaba de un techo o de un pescante. Probablemente, aludía a las del templo de Salomón ${ }^{53}$. En 1505 el mercader Francesc Ballester tenía guardados en una habitación de su casa tres ejemplares, uno grande de nueve brazos y dos pequeños, de seis ${ }^{54}$. Aunque la descripción del notario, como en otras ocasiones es parca y no nos indica la procedencia ni el material de realización de estas obras, por las características formales podemos suponer que su origen estaba en la zona de Flandes y la materia era el latón. Además, se detalla en el mismo inventario que había una cesta en el que había les branques dels dits selamons, es decir se habían desmontado los brazos para no ocupar espacio.

Las lámparas o candelabros de corona se caracterizan por tener en su columna central una figura escultórica, realizada a la cera perdida, y diferentes brazos, superpuestos en dos niveles. En la mayoría de ejemplares destinados a la exportación, eran desmontables. Las piezas más originales eran las utilizadas en iglesias o capillas, como por ejemplo la del Hospital de San Juan de Brujas ${ }^{55}$ o la creada por Peter Vischer para la Lorenzkirche de Nuremberg ${ }^{56}$, eran piezas únicas, de gran originalidad. Los ejemplares más simples, de dimensiones más reducidas, aparecen representados sistemáticamente en los interiores pictóricos flamencos, de ahí la denominación genérica de “tipo Arnolfini”, al aparecer representada una de ellas en la famosa pintura de Jan van Eyck de 1434 (National Gallery, Londres). Un modelo que vuelve a aparecer en obras posteriores, como la pintada pendiendo del techo en la tabla central del Altar del Santísimo Sacramento de Dieric Bouts pintado hacia 1464-67 (Sint Pieterskerk, Lovaina).

Las piezas de Francesc Ballester tenían las esculturas de un león y de un ángel ${ }^{57}$. La del félido debía ser muy similar al "tipo Arnolfini", aunque no conservamos ningún fragmento en el contexto insular, el tipo tiene muchos paralelos. La del Museo Diocesano de Solsona (Cataluña) ${ }^{58}$ presenta en

${ }^{44}$ F. SEVILLANO COLOM, Un manual mallorquín de mercadería medieval, in Anuario de Estudios Medievales 9, 1974-1979, p. 517-530; O. VAQUER BENNASAR, El comerç marítim de Mallorca 1448-1531, Mallorca, 2001, p. 451.

${ }^{45}$ En el apartado de metales del libro del Consulado catalán de Brujas se consignan de forma preferente las «basines o conques», véase G. LLOMPART, Anònim. Bacina, in Mallorca Gòtica, Palma, 1998, p. 322.

${ }^{46}$ En 1395 Johan Smalrich tenía en su escritorio a parte de telas de Flandes, Toscana y Calabria, un quintal, unos 40 kg, de platos de latón de Flandes, G. LLOMPART, La pintura medieval mallorquina. Su entorno cultural y su iconografía, Palma, 1980, vol. 2, p. 18.

${ }^{47}$ M. BARCELÓ CRESPÍ, Luxe i interior op. cit. (n. 38), p. 309-332.

${ }^{48} \mathrm{ARM}, \mathrm{M}-612$, fol. 168. El objeto de latón ocupaba una situación preeminente, a pesar de ser de una materia no noble, en la casa de un noble que disponía de gran cantidad de objetos de plata.

${ }^{49}$ G. LLOMPART, Anònim. Bacines, in Mallorca Gòtica, Palma, 1998, p. 323.

${ }^{50}$ Los ciudadanos podían desarrollar actividades comerciales a gran escala. Este estamento a finales del XV, se integró en el brazo noble, pasando a ser denominados ciudadanos militares, detentando los mismos derechos honoríficos, procesales y penales, A. PLANAS ROSSELLÓ, Los jurados de la Ciudad y Reino de Mallorca (1249-1718), Palma, 2005, p. 152-153.

${ }^{51}$ M. BARCELÓ CRESPÍ, Luxe i interior op. cit (n. 38), p. 329.

${ }_{52}^{2}$ Una de las referencias más antigua es el salamó de bañas de cero amb una figura enmig, que tenía en su casa Pere Mates, maestro de obras, en 1355. En 1403 se menciona otro de banyes, es decir como el anterior realizado con cuernos de ciervo, que tenía en su parte central un jinete cabalgando un león. Estas referencias aluden a otro tipo de candelabros comunes en la época, G. LLOMPART, La pintura medieval op. cit. (n. 46), vol. 1, p. 239.

${ }_{53}$ A. M. ALCOVER, F. B. MOLL, Diccionari català-valencià-balear, Palma, 1975, vol. 9, p. 695; J. COROMINES, Diccionari etimològic i complementari de la Llengua Catalana, Barcelona, 1980, vol. 7, p. 621.

${ }_{54}$ ARM, M-612, fol. 202v, M. BARCELÓ CRESPÍ, Luxe i interior op. cit (n. 38), p. 322-323.

55 Atribuida a un taller flamenco de la segunda mitad del XV, J. BIALOSTOCKI, El arte del siglo XV. De Parler a Durero, Madrid, 1998, p. 333.

${ }^{56}$ W. D. WIXON, The Art of Nuremberg Brass Work, in Gothic and Renaissance Art in Nuremberg 1300-1550, New York, 1986, p. 78-79.

57 Item un salamó de VIIII branques gran en què y ha un àngell demunt. Item un altra selamó poquet ab un lahó de sobra, de sis branques ARM, M-612, fol. 202v. ${ }_{58}^{8}$ J. BARRACHINA NAVARRO, Llum gòtic, in Thesaurus-estudis: l'art als bisbats de Catalunya 1000-180o, Barcelona, 1986, p. 224-225; J. BARRACHINA NAVARRO, Llum, in Catàleg d'art romànic i gòtic. Museu Diocesà i Comarcal de Solsona, Solsona, 1990, p. 274-275. 


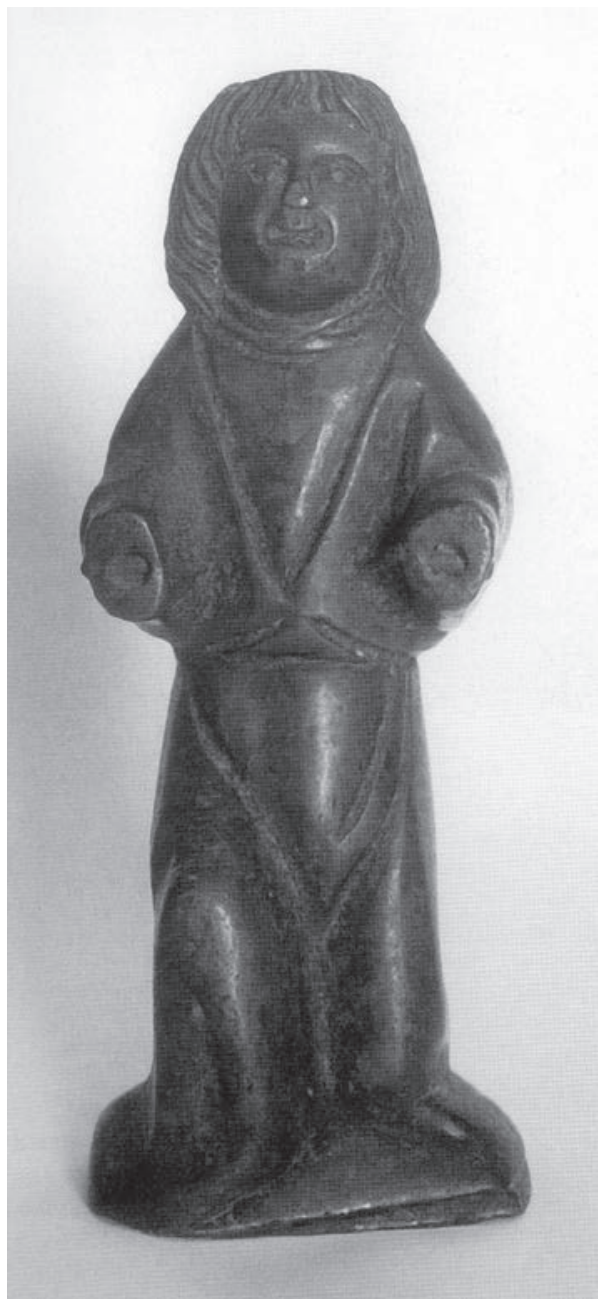

Fig. 3. Fragmento de lámpara. Àngel, taller flamenco o alemán, finales del s. XV-inicios del XVI, monasterio del Puig de Pollença (Mallorca). Fot. A. Pons

la parte superior un león sentado sobre las piernas traseras, realizado a la cera perdida y después retocado en fríi ${ }^{59}$. Es una pieza muy ornamentada ya que tiene tres imágenes figuradas, en la parte inferior de la columna central de la lámpara, con otra cabeza de león que muerde un eje horizontal rematado con dos pequeñas cabezas de canes. Los seis brazos que conforman la corona son de chapa de latón con decoración vegetal estilizada. En este sentido, conviene precisar que para facilitar el desmontajey posterior montaje de los brazos, presenta una numeración para poderlos identificar y volver a colocar una vez desmontados.

La imagen del ángel se puede relacionar con un fragmento conservado en las colecciones del monasterio del Puig de Pollença (Mallorca), una pequeña institución religiosa hoy desaparecida fundada en el siglo XIV ${ }^{60}$. La escultura está realizada en bronce y datada a finales del XV o inicios del XVI ${ }^{61}$, está perforada verticalmente, característica que comparte con el resto de figuras hasta ahora mencionadas (fig. 3). En el Victoria and Albert Museum (Londres) existe

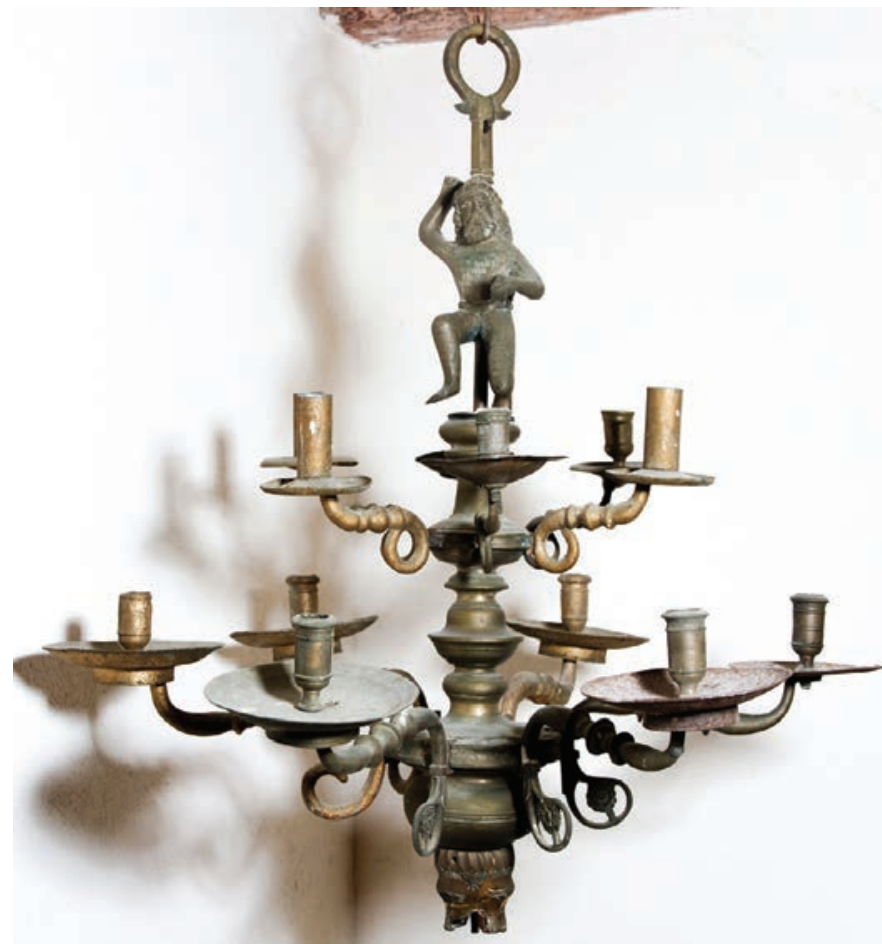

Fig. 4. Lámpara de techo, taller de Alemania o Nuremberg, segunda mitad del s. XV-primera mitad del s. XVI, $75 \times 75 \mathrm{~cm}$. Palma, Monasterio de Santa María de la Real (Palma)

un ejemplar completo y de mayor calidad, atribuido a talleres alemanes hacia 1480-1520, que es tenante de escudo ${ }^{62}$. La pieza mallorquína también podría haber sostenido un escudo, ya que ha perdido parte de los brazos, que se habían fundido por separado. Si comparamos los rasgos faciales de las caras de las dos imágenes, es evidente la escasa calidad de nuestro ejemplar. El ciudadano Joanot Ros tenía en 1537 otro candelabro con ángel ${ }^{63}$.

Aunque las piezas mallorquinas no corresponden a los ejemplares de mayor originalidad y creatividad artística, realizados para clientes e instituciones cercanas a los talleres productores, sin embargo son claros ejemplos de la difusión y éxito de un tipo de candelabro que debió substituir modelos más simples realizados con otros materiales. Además, ayudan a difundir temas iconográficos y esquemas compositivos nuevos, aunque se trate de ejemplares realizados de forma seriada, en unos diseños pensados para repetirse muchas veces. Las importaciones aún están bien documentadas durante la primera mitad del XVI. El orfebre Jeroni Sanglés tenía un candelabro con la figura de la Virgen María ${ }^{64}$.

Estas obras también, dentro del fenómeno de multiplicación de los objetos en los interiores, pueden trasladar iconografías profanas menos frecuentes. En el Monasterio de Santa María de la Real, fundación cisterciense del siglo XIII próxima a Palma, se conserva un candelabro atribuido a talleres alemanes y fechado en el s. XV (fig. 4). Se trata de una lámpara de 12 brazos. Algunos de hierro y procedentes

59 En el Metropolitan Museum de Nueva York se conservan otros dos ejemplares fechados a mediados del siglo XV. En los dos, la figura del león difiere del ejemplar de Solsona, en un caso, está con la boca abierta (№ de inventario 64.101.1531a-h), mientras que el segundo está mordiendose la lengua (№ de inventario 64.101.1530a-g).

${ }^{60}$ M. J. BORDOY BORDOY, El Monestir del Puig de Pollença: la seva història (1348-1564), Pollença, 2005.

${ }^{61}$ El Puig de Pollença: espiritualitat, història, art, Pollença, 1998, p. 98.

${ }^{62}$ № de inventario 2398-1855. Otro ejemplar similar forma parte de la colección del Metropolitan Museum of Art ( № de inventario 47.101.50a, b)

${ }^{6}$ G. LLOMPART, La pintura medieval op. cit. (n. 46), vol. 1, p. 240.

${ }^{64}$ Se trata de otra iconografía característica. Los ejemplares más sofisticados como el de la colección del Metropolitan Museum of Art de Nueva York (Núm. inv. 1975.1.1422) presentan la imagen en el interior de un sofisticado tabernáculo que ocupa la zona central, F. CHOLTEN, European Sculture and Metalwork in the Robert Lehman Collection, New York, 2011, p. 218. 


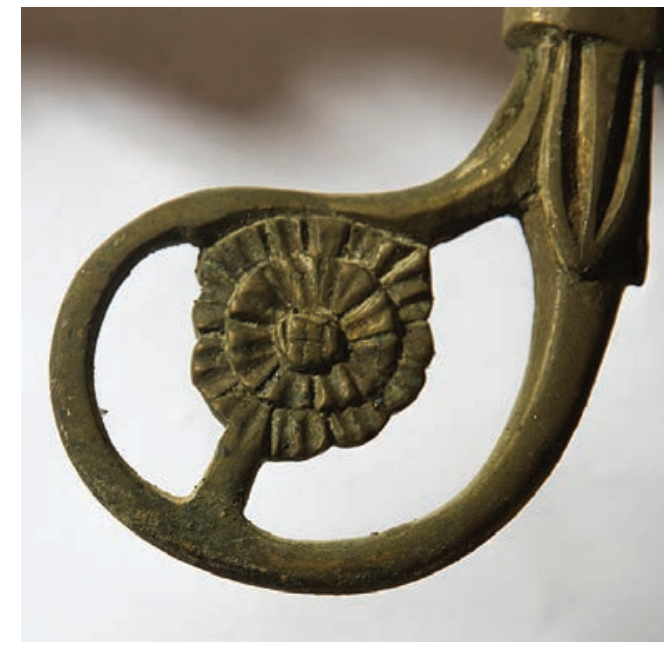

Fig. 5. Decoración vegetal. Detalle de la fig. 4

de una restauración de cronología posterior, mientras que los originales son más gráciles y presentan en el extremo inferior una decoración en forma de rosa (fig. 5). El vástago central se caracteriza por la combinación de nudos cónicos, que en la parte inferior culmina con una cabeza de león (fig. 6), labrada con trazos cincelados profundos, del cual pendería una anilla en su boca. En su parte superior, antes de la anilla que permite suspenderla del techo, presenta la figura de un salvaje amenazante, que ha perdido su garrote, con mechones de vello por todo su cuerpo. El salvaje (fig. 7), identificado por el Dr. Llompart como babuino ${ }^{65}$, tiene otros paralelos que se atribuyen a producciones seriadas realizadas en Alemania en la segunda mitad del s. XV, probablemente en la zona de Nuremberg, donde sus talleres entablaron competencia con los Países Bajos en la elaboración de lámparas en forma de corona y aguamaniles. En el Victoria and Albert Museum de Londres ${ }^{66}$, se custodia un salvaje arrodillado y en posición de golpear con un palo, en este caso de latón. Otro ejemplar pertenece a la colección del Cleveland Museum of Art ${ }^{67}$. Otros hombres salvajes en posturas similares y de idéntica escala se exhibieron en una exposición en Hamburgo en $1963^{68}$. El ejemplar mallorquín corrobora que estas piezas formaban parte de candelabros, aspecto que ya se insinuó en sus respectivas fichas de catálogo. A pesar de las grandes similitudes entre todos ellos, como por ejemplo el cinturón doblado en helicoidal y el pañuelo de su cabeza, otros detalles dejan claro las variaciones en los modelos de cera realizados para la fundición, aspecto que denota la existencia de varios talleres o la repetición de un mismo original a lo largo de una cronología indeterminada. Aunque de manera hipotética, una observación detallada de la escultura de nuestro salvaje, en especial de la mano izquierda y de una de las rodillas, nos conduce a pensar que en origen se ideó como tenante de escudo, una característica que comparte con los anteriores y que se deduce de otras representaciones. Una

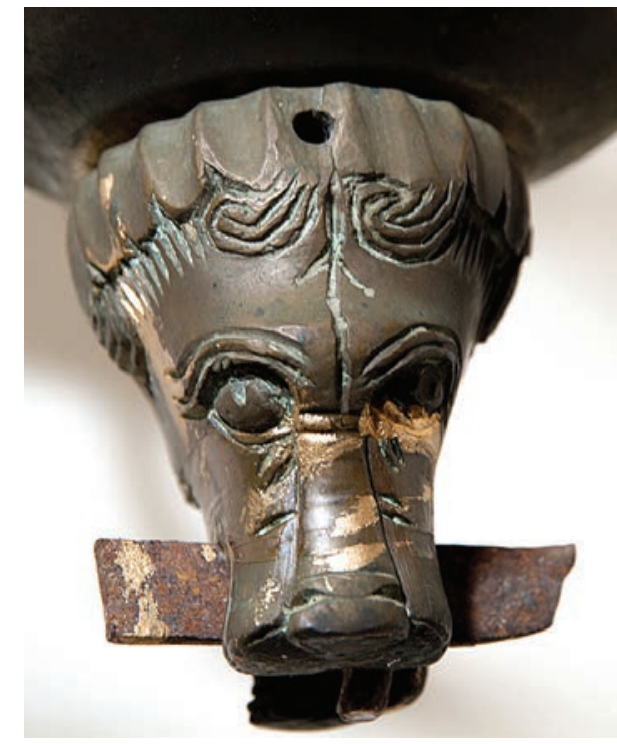

Fig. 6. Cabeza de león. Detalle de la fig. 4

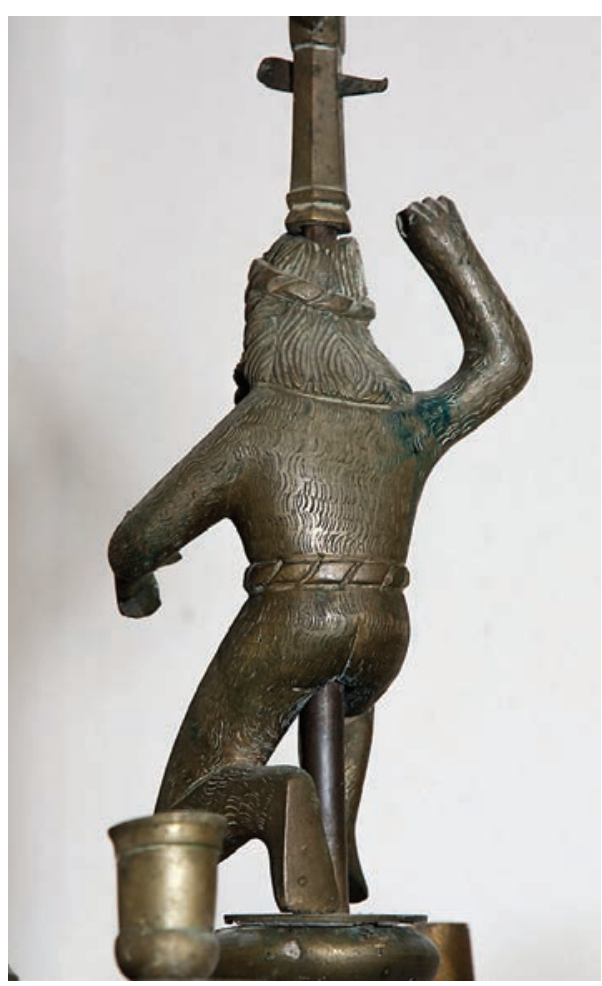

Fig. 7. Hombre salvaje. Detalle de la fig. 4

vez perdidos estos atributos, tal vez por una reinterpretación iconográfica, la lámpara del salvaje pudo asimilarse a San Onofre ${ }^{69}$, un santo venerado en este monasterio, como atestiguan diversas obras pictóricas posteriores. Los salvajes forman parte del imaginario colectivo medieval, aunque las representaciones que se han conservado en Mallorca son escasas ${ }^{70}$, tan sólo alguna imagen esculpida, por lo que cobra más valor la obra conservada en la Real.

\footnotetext{
${ }_{65}$ G. LLOMPART MORAGUES, Mallorca-Flandes op. cit. (n. 14), p. 71.

${ }^{66}$ № de inventario M168-1937.

${ }^{67}$ W. D. WIXON, Four Late Gothic Additions to the Medieval Treasury, in The Bulletin of The Cleveland Museum of Art 56, 1969, pp. 328-330; G.G.-H., Wild man, in T. HUSBAND (ed.), The Wild Man. Medieval Myth and Symbolism, New York, 1980, p. 176.

${ }^{68}$ L. LOTTE (ed.), Die wilden Leute des Mittelalters, Museum für Kunst und Gewerbevol., Hamburg, 1963, núm. 13-14, 16-18.

${ }^{69}$ R. BARTRA, El salvaje en el espejo, Barcelona, 1996, p. 90-91; J. M. AZCÁRATE RISTORI, El tema iconográfico del salvaje, in Archivo Español de Arte 21, 1948, p. 81-99.

${ }^{70}$ La mayor parte se trataba de telas o pinturas, G. LLOMPART, La pintura medieval op. cit. (n. 46), vol. 2, p. 88.
} 


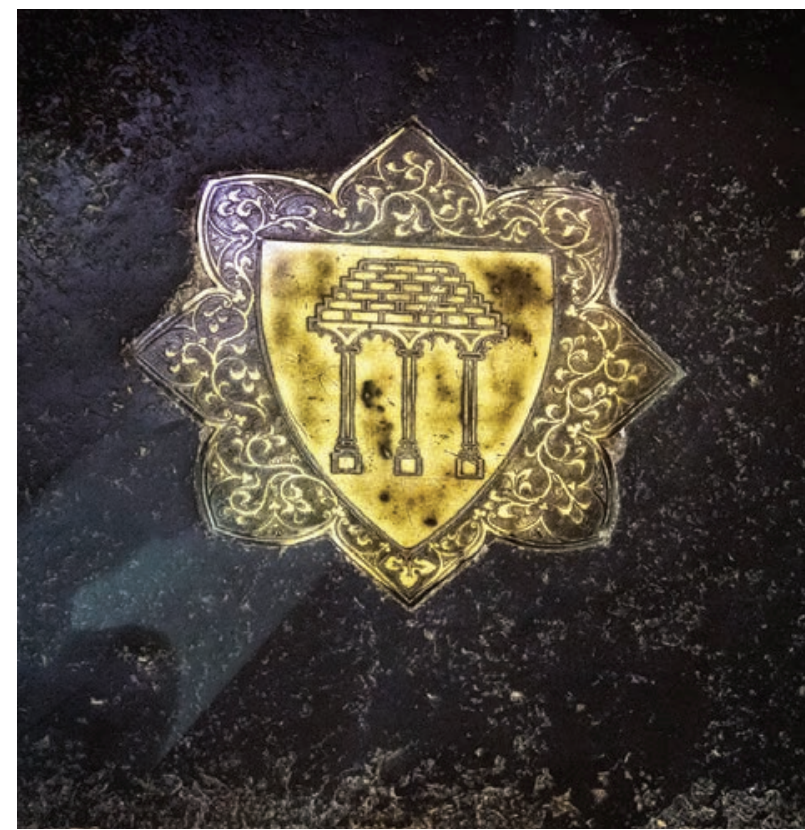

Fig. 8. Escudo de la familia Pont, taller flamenco, s. XV, Catedral de Mallorca (Palma)

Asociado a las conexiones con Flandes y a los trabajos con metal de esa zona (fig. 8), se conserva en la Catedral de Mallorca un escudo familiar aplicado sobre una piedra negra en una tumba de la familia Garau-Pont ${ }^{71}$, fechado por W. J. Hemp a inicios del siglo XV72. Se trata de un escudo parlante ${ }^{73}$, que incorpora la imagen de un puente aludiendo e interpretando gráficamente el linaje de la familia. Aunque tan sólo podemos citar dos ejemplos más, parece que este tipo de decoración relativamente poco monumental, pero sí llamativa por el contraste del dorado sobre el negro, tuvo una cierta aceptación en especial entre las familias con vínculos con el arte de la mercadería.

\section{LA TAPICERÍA}

Los tapices de Arras, después Tournai, Lilley Bruselas, en diferentes calidades, se difundieron por toda Europa ${ }^{74}$, entre otros factores por su practicidad como elemento decorativo y su facilidad de transporte. Además, la posesión de telas ricas y de tapices flamencos era interpretada como un signo de prestigio, poder y ostentación. Buena prueba de ello son las colecciones atesoradas por Alfonso de Aragón y su esposa María ${ }^{75}$. La corte del Magnánimo ha sido descrita recientemente, en relación a los intercambios artísticos, como un ejemplo de la "globalización artística" ${ }^{6}$, que se produjo en ella, al confluir las corrientes artísticas presentes en la Corona de Aragón, con el arte flamenco-nórdico y el humanismo italiano. Aunque este último, ha sido considerado como prevalente por la historiografía, no se pueden olvidar las importantes conexiones establecidas con la corte de Borgoña. Si nos centramos en el caso de los tapices, la fuerte demanda del rey a los centros productores, donde disponía de agentes y se realizaron compras muy específicas, tuvo como resultado la configuración de una espléndida colección en el palacio del Castel Nuovo en Nápoles ${ }^{77}$. El aprecio a los tapices flamencos tendrá su continuidad en los ambientes cortesanos de Juan II y de los Reyes Católicos ${ }^{78}$. Estas dinámicas de los ambientes más selectos 79 , acabaron generando un mayor interés por esta manifestación artística en los territorios de la corona, aunque, como sabemos, ya era apreciada en el siglo $\mathrm{XIV}^{80}$. No consta que en la isla se estableciese ningún artesano que tuviese conocimientos para realizar tapices en este período ${ }^{81}$, lógicamente, las conexiones marítimas hacían más fácil recurrir a intermediarios y encargar la obra en la zona de origen. En cambio, en Tortosa sí que se estableció un centro de producción entre 1425 y $1513^{82}$, si bien, por falta de datos se desconoce si estos talleres recibieron demandas específicas de otras ciudades de la Corona de Aragón.

Este interés que fue emulado por los nobles y los altos dignatarios de la corte, es difícil de detectar en el caso del Reino de Mallorca, en parte debido a la falta de unas cortes propias. La transmisión de estos gustos y modas puede seguirse con más intensidad analizando los bienes de los Jurados de la Ciudad y del Gran i General Consell, que detentaban el poder ejecutivo y de representación frente a la Corona y, en especial, con aquellos mercaderes más acaudalados.

Una proyección de estos ambientes cortesanos la podemos rastrear en el inventario de algunos de los bienes del obispo de Mallorca Fray Juan García. Este prelado, natural de

\footnotetext{
${ }^{7}$ M. BARCELÓ CRESPÍ, B. COLL TOMÀS, G. ROSSELLÓ BORDOY, op. cit. (n. 17), p. 34-35; G. LLOMPART, La pintura medieval op. cit. (n. 46), vol. 2, p. 17. ${ }^{72}$ W. J. HEMP, Algunas lápidas de bronce españolas, olvidadas, in BSAL 20, 1924-1925, p. 208-210.

73 P. D. MONTANER, Blasons i persones a la Seu, in A. PASCUAL (ed.), La Seu de Mallorca, Palma, 1995, p. 327-339.

${ }^{74}$ M. THOMAS, C. MAINGUY, S. POMMIER, El tapiz: una historia de un arte, Barcelona, 1985. El papel de las demandas de los duques de Borgoña y de otros miembros de la corte es fundamental para el desarrollo de determinadas temáticas, véase S. SCHNEEBALG-PERELMAN, La tapisserie des Pays-Bas sous les ducs de Bourgogne, Bruxelles, 2003.

75 S. ALDANA FERNÁNDEZ, Iconografia medieval valenciana. Los tapices de la Reina María, esposa de Alfonso el Magnánimo, in Archivo de Arte Valenciano 73, 1992, p. 26-36.

${ }_{76}^{7} \mathrm{~J}$. V. GARCÍA MARSILLA, El poder visible. Demanda y funciones del arte en la corte de Alfonso el Magnánimo, in Ars Longa 7-8, 1996-1997, p. 33-47. 77 G. TOSCANO, Alfonso el Magnánimo y el norte. Obras flamencas en las colecciones reales, in A la búsqueda del Toisón de Oro. La Europa de los Príncipes. La Europa de las Ciudades, 2007, p. 347-363; J. V. GARCÍA MARSILLA, Intercanvis culturals i lideratge estètic. La demanda artística d'Alfons el Magnànim en el context de l'Europa del quatre-cents, in Maria Rosa TERÉS (ed.), Capitula facta et firmata. Inquietuds artístiques en el quatre-cents, Valls, 2011, p. 121. ${ }^{78}$ A la manera de Flandes. Tapices ricos de la Corona de España, Madrid, 2001; M. Á. ZALAMA, Primacía de los tapices entre las artes figurativas en España en los siglos XV y XVI, in F. CHECA CREMADES, B. J. GARCÍA GARCÍA (ed.), Los Triunfos de Aracne. Tapices flamencos de los Austrias en el Renacimiento, Madrid, 2011, p. 17-36.

${ }^{79}$ A. SERRA DESFILIS, La imagen construida del poder real en la Corona de Aragón (siglos XIII-XV): Casas, ceremonial y magnificencia, in Res publica 18, 2007, p. 35-57.

${ }^{80}$ M. OLIVAR, Els tapissos francesos del rei En Pere el Cerimoniós, Barcelona, 1986.

${ }^{81}$ En 1398 consta el pago a Robinet, «mestre de draps de ras», por un gremial, paño cuadrado para determinados usos litúrgicos, con la figura de la Asunción para el Obispo de Mallorca, G. LLOMPART, Bordadores medievales en Mallorca, in BSAL 45, 1980, p. 208.

${ }^{82}$ J. VIDAL FRANQUET, El centro de producción de tapices de Tortosa (ca. 1425-1493/1513), in Ars Longa 16, 2007, p. $23-37$.
} 
Calatayud, obispo de Siracusa, confesor, consejero y albacea testamentario de Alfonso el Magnánimo, fue un miembro destacado de la corte que ejerció cargos diplomáticos en Roma. En 1459 después de la muerte del rey, retornó con el resto de mallorquines integrantes de la corte ${ }^{8_{3}}$, a su diócesis de la que había estado ausente desde su nombramiento en 1447. Falleció, tan sólo un mes después de su llegada ${ }^{84}$. La riqueza de sus bienes se refleja en los 52 objetos de plata, buena parte de servicio de mesa y otros de uso litúrgico, algunos de ellos con "la senyal del bisbe". A este conjunto, se le deben sumar los 9 tapices que debían ornamentar la sala o salas destinadas a las celebraciones del obispo. No se indica el lugar de elaboración de estos tapices, pero vistos los encargos de la corte cabe suponer que por las dimensiones y la denominación "de ras" ${ }^{5}$, serían obras importadas desde el norte de Europa. Las piezas con figuras eran grandes y en una de ellas se describe que estaba representado el tema de la "istoria de Virgili", ${ }^{86}$ algún tema relacionado con la Eneida y la fundación de Roma por los troyanos ${ }^{87}$. Tenemos noticia de estos bienes por una carta fechada en 1460 que fue enviada por Juan II $^{88}$ a los Canónigos y Capítulo de la Catedral de Mallorca, en la que se comprometía a responder o restituir el valor de estos bienes si eran reclamados por el sucesor en el obispado. Desconocemos el paradero final de estos tapices que, tal vez, acabaron engrosando la colección de Juan II que, según el inventario realizado en 1479 tenía unas cien piezas de notable calidad ${ }^{89}$. Más allá del interés del monarca por unas obras de gran calidad, es probable que estas piezas historiadas del obispo tuviesen alguna relación con los encargos reales.

Si atendemos a las fuentes literarias coetáneas, y nos fijamos en las descripciones de interiores que aparecen en el Tirant lo Blanch ${ }^{90}$, es fácil entender que la costumbre de utilizar tapices se extendiese entre miembros adinerados de los diferentes estamentos. La sala o comedor ${ }^{91}$, sinónimos en este período, en la planta noble de las casas bajomedievales más privilegiadas de la Ciudad de Mallorca era donde se acumulaban la mayoría de objetos y muebles, significantes de la "posición social de la familia"92. Aunque este espacio variaba tipológicamente en función de las dimensiones del inmueble, a partir de las estructuras parcialmente conservadas y la documentación escrita, pueden fijarse algunas de sus principales características. Así, era un espacio de planta rectangular, con ventanas abiertas a la calle y, en ocasiones, a un patio interior. Estaba cubierto con artesonados de madera, con decoración pictórica de influencia mudéjar, datados a lo largo del siglo XIV; mientras que los de la centuria siguiente no contaban con decoración. La decoración de este interior era austera, sin pinturas ${ }^{93}$, y se caracterizaba por pequeños retablos y elementos móviles, como tapices y draps de pinzell94.

En la sala de Salvador Sureda ${ }^{95}$, caballero, en 1495 había diferentes elementos que de forma clara nos remiten a los interiores flamencos, junto con muchísimos otros objetos de otras procedencias. Entre el mobiliario destacaba el tinell o aparador de madera de Flandes, no sabemos si la pieza fue importada o si es una denominación determinada por el tipo de mueble o por haber sido realizado con este material nórdico en la ciudad. Sobre el tinel había numerosos objetos de latón que, aunque no se indique su origen, presuntamente eran importados: dos jarras con picos, dos platos o bassinas, una concha de leutó gran ab sos peus, un candelabro que estaba clavado al mueble. Sobre el aparador, clavado a la pared, había un tapiz o drap de ras con figuras. Además, otro elemento significativo, era el bastidor de madera con sus cuerdas que estaba destinado a colgar tapices, que estaban guardados en otro espacio de la casa para evitar su deterioro. Finalmente, para completar este conjunto había encima de un portal que conducía a la despensa de la casa, hun ymatge obre de Flandes dels Tres Reys ab ses portas, es decir, un retablo esculpido con puertas de madera con la Epifanía. Finalmente, un espejo grande, enbutit obre de Flandes, probablemente encastado en madera. Los espejos son otro índice característico del interior flamenco que podemos rastrear con extrema facilidad en la pintura coetánea. Si bien es cierto, que la isla estaba conectada con el mundo veneciano y es desde ahí donde llegan mayoritariamente los espejos de vidrio, también son frecuentes los nórdicos ${ }^{96}$.

\footnotetext{
83 Francesc Aixaló y Joan Valero fueron secretarios reales, mientras que Mateu Malferit, consejero. Todos ellos participaron en la difusión de las ideas de la corte e introdujeron ideas humanistas y aspectos renacentistas en la isla. Véase M. BARCELÓ, G. ENSENYAT, Els nous horitzons culturals a Mallorca al final de l'edat mitjana, Palma, 2000, p. 17-18

${ }^{84}$ M. BARCELÓ CRESPÍ, G. ENSENYAT PUJOL, Clergues il-lustrats: un cercle humanista a l'entorn de la Seu de Mallorca, 1450-1550, Palma, 2013, p. 17-18

${ }^{85}$ Es la denominación de tapiz utilizada en la documentación medieval en catalán. Es equiparable a «paños de raz» en castellano o «arrazzi» en italiano.

${ }^{86} \mathrm{G}$. LLABRÉS, Inventario de algunos muebles del obispo mallorquín fray Juan García, in BSAL 1, núm. 3, 1885, p. 1-3.

${ }^{87}$ M. BARCELÓ CRESPÍ, G. ENSENYAT PUJOL, op. cit. (n. 83), p. 18.

${ }^{88}$ Para las relaciones políticas del monarca con el Reino de Mallorca, véase R. URGELL HERNÁNDEZ, El Regne de Mallorca a l'època de Joan II: la guerra civil catalana i les seves repercussions, Palma, 1997. No consta que el sucesor en el obispado, Arnau de Marí i de Santacília (1460-1464), reclamase estas piezas. ${ }^{89}$ M. Á. ZALAMA, J. F. PASCUAL MOLINA, Tapices de Juan II de Aragón y Fernando el Católico en La Seo de Zaragoza, in Boletín. Museo e Instituto Camón Aznar 109, 2012, p. 288-296.

$9^{\circ}$ «(...) el rey y la reyna con todos los estados entramos dentro de un gran patio, todo al derredor entoldado de paños de ras, labrados de oro y seda y de hilo de plata de diversas ystorias, las ymágenes fechas por arte de sotil arteficio», J. MARTORELL, op. cit. (n. 40), vol. 2, p. 87.

${ }^{91}$ O. PÉREZ MONZÓN, op. cit. (n. 39), p. 276-279.

${ }_{92}^{2}$ M. BARCELÓ CRESPÍ, G. ROSSELLÓ BORDOY, La casa gòtica a la Ciutat de Mallorca, Palma, 2009, p. 73.

${ }_{93}$ Los restos de pintura mural conservados en la casas del patriciado urbano, recuperados y sistematizados por el Dr. Morata, pueden fecharse también en el siglo XIV y serían de tipo geométrico-floral (véase T. SABATER REBASSA, La pintura a l'època del Regne Privatiu, in Bellver 1300-200o, 70o anys del castell, Palma, 2003).

94 J. SASTRE MOLL, L'obra pictòrica com element decoratiu, sumptuari i devocionari a les llars medievals mallorquines, en el trànsit a la Modernitat, in BSAL 59, 2003, p. 47-88.

${ }_{95}$ M. BARCELÓ CRESPÍ, Luxe i interior op. cit. (n. 38); ARM, Not. P-451, fol. 96-136.

${ }_{96}^{6}$ Por una razón, la mayor calidad de las producciones alemanas, en concreto de Nuremberg y de la zona de Alsacia-Lorena. Los espejos convexos ofrecían una imagen panorámica con un mínimo de materia vítrea, si bien, antes era de metal pulido, en el siglo XV se produce una gran difusión de estas producciones vítreas, S. LAGABRIELLE, Miroirs et faiseurs de miroirs au Moyen Âge et à la Renaissance, in Miroirs. Jeux et reflets depuis l'Antiquité, Paris, 2000, p. 115-116.
} 


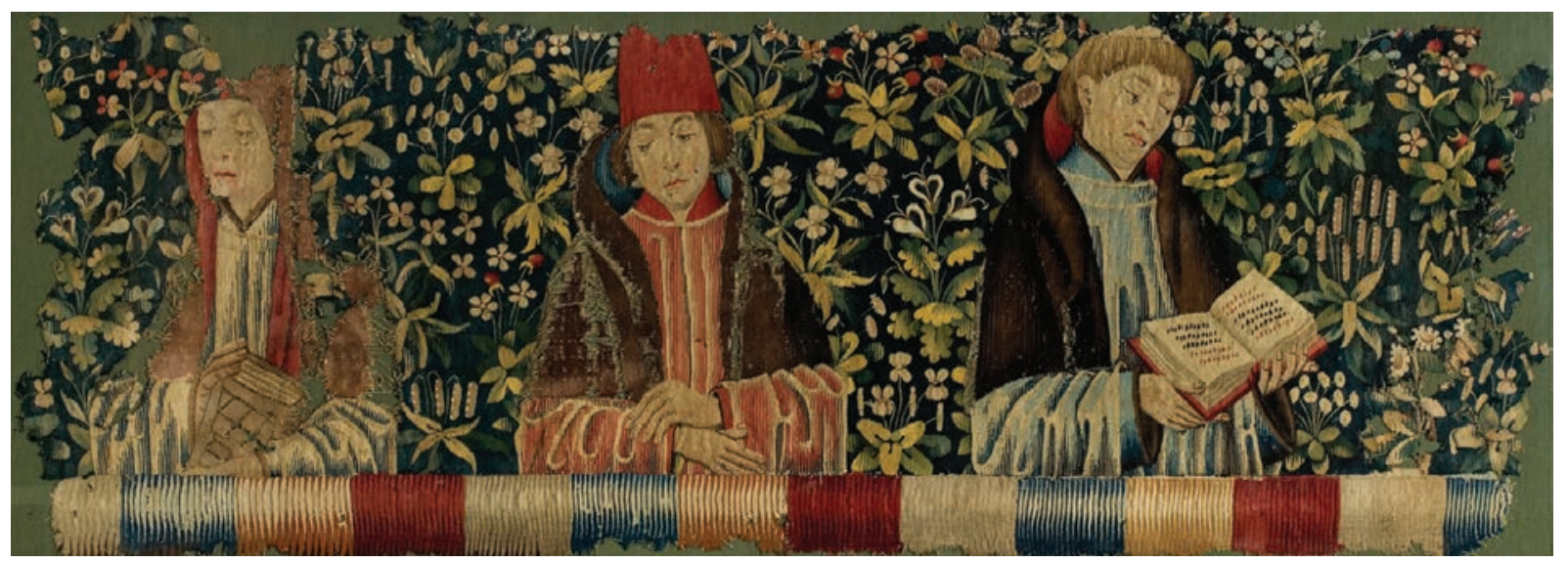

Fig. 9. Tapiz, taller de Bruselas, ca. 1500-1515, DA05/16/065, (CMuseo de Mallorca (Palma)

En 1505 en la casa de Gregori Burgues, procurador del Reino de Mallorca y miembro de la familia más poderosa, rica e influyente a finales del siglo $\mathrm{XV}^{97}$, en la sala principal de su casa, tenía dos bastidores con sus pequeñas poleas para entoldar la sala con tapices. No estaban colgados, para evitar su rotura, mientras que en una recámara sí, había uno grande y otro pequeño, figurados ${ }^{98}$.

La corte de Borgoña estaba fascinada por la Historia antigua y en concreto por la legenda de Troya ${ }^{99}$, con algunos de sus encargos a talleres de Tournai en la segunda mitad del siglo XV se renovó esta temática del tapiz. Aunque este tema ya estaba constatado a finales del XIV en Barcelona ${ }^{100}$, en Mallorca aparecen numerosos ejemplos de tapices y de obras menores, que pueden relacionarse con esta renovación temática y la difusión por el resto de talleres de la zona flamenca ${ }^{101}$, aunque sean obras probablemente de escasa calidad pictórica. En la sala del mercader P. de Villalonga en 1486 había un tapiz con la Ystòria de Briseida e de grechs e troyans ab hun bastiment de fust, otro ejemplo lo tendríamos en un tapiz con la representación de las Amazonas que tenía en 1537 el ciudadano Joanot Ros ${ }^{102}$.

Emulando a los nuevos ricos, algunos menestrales, en pro de la ilusión de ascenso social, aunque no se podían permitir los lujosos tapices de la nobleza, sí que podían acceder en cambio a obras más modestas, de inferior calidad, como los draps de pinzell ${ }^{103}$, pero que cumplían una función similar de decoración móvil y figurada de los interiores. Además, a través de estos objetos compartían las temáticas de moda, creadas para grandes comitentes, que en el caso de los tapices habían sido imitadas y versionadas por otros talleres tapiceros. Entre los muchísimos ejemplos, el tejedor Bartomeu Gomila en 1485 tenía un drap de pinzell con Venus, Juno y Palas ${ }^{104}$.

Los miembros del Gran i General Consell, la asamblea estamental del Reino de Mallorca, trataron en 1518 el estado de abandono de la sala de deliberaciones y, en concreto, de las cortinas que pendían en ella ${ }^{105}$. El deterioro era tan flagrante que se sentían avergonzados, ya que ninguno de ellos tendría unas telas como esas en sus casas. Finalmente, se acordó que se propondría a los Jurados que se encargasen unos tapices en Flandes, en concreto uns bons draps ${ }^{106}$. Probablemente, estas piezas no se debieron realizar, ya que no tenemos más noticias, pero son un buen ejemplo de la posibilidad de encargar proyectos concretos en los talleres flamencos. El tema que querían representar era la historia de la conquista feudal de Madîna Mayûrqa por las

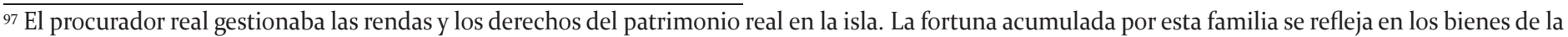
casa mayor de los Burgues, las más valorada de la ciudad, muy alterada por reformas contemporáneas de la que se conserva un grabado publicado en 1881. En 1505 la casa mayor estaba en obras y era la suma de tres casas. Véase: J. JUAN VIDAL, E. SÁNCHEZ NIEVAS, Els Burgues: una Nissaga de poder, Palma, 2003, p. 148-158, 160-161, 228-230,

${ }_{98}^{8}$ En el porche tenía uno desgarrado, esquinçat, como otros dos que tenía en otra propiedad, que sí estaban tendidos en la pared. Entre sus bienes se anotan otros procedentes de Flandes, como una mesa de roble y un paquete de pieles de gato, pells de gats de Flandes que són dotze o tretze pells, ARM, Not. M-612, fol. 171-199.

${ }^{99}$ F. JOUBERT, La tapisserie, in C. PRIGENT (ed.), Art E société en France au XVe siècle, París, 1999, p. 438; véase el reciente estado de la cuestión realizado sobre la Tapicería de la Guerra de Troia en L. WEIGERT, The Art of Tapestry: Neither Minor nor Decorative, in From Minor to Major. The Minor Arts in Medieval Art History Pennsylvania, 2012, 114-121.

${ }^{100}$ M. R. TERÉS I TOMÁS, Art profá i vida quotidiana entorn a 1400: els inventaris barcelonins, in Acta historica et archaeologica medievalia 19, 1998, p. $302-306$.

${ }^{101}$ F. JOUBERT, Les tapisseries de la fin du Moyen Âge: commandes, destination, circulation, in Revue de l'Art 120, 1998, p. 94-95.

${ }^{102}$ J. SASTRE MOLL, op. cit. (n. 9), p. 69; G. LLOMPART, La pintura medieval op. cit. (n. 45), vol. 2, p. 88.

${ }^{103}$ Denominación aplicada a telas pintadas o sargas, presentes en las casas de los burgueses, «para los miembros de esta clase social los draps de pinzell debían de constituir una especie de sucedáneo de los suntuosos y caros draps de ras que decoraban las mansiones de la aristocracia», J. MOLINA I FIGUERAS, Arte, devoción y poder en la pintura tardogótica catalana, Murcia, 1999, p. 47.

${ }^{104}$ M. BARCELÓ, G. ENSENYAT, op. cit. (n. 82), p. 134.

${ }^{105}$ R. PIÑA HOMS, El Gran i General Consell. Asamblea del Reino de Mallorca, Palma, 1977, p. 87; C. CANTARELLAS CAMPS, F. TUGORES TRUYOL, A propòsit de l'església de Sant Andreu i de la capella de Sant Eloi a partir del segle XIV (Casa de la Universitat de Ciutat de Mallorca-Ajuntament de Palma), in BSAL 70, 2014, p. 126.

${ }^{106}$ «Noresmenys no ignoren V. m. ab quanta vergonya sta la sala de baix, ahont fem continua residencia per esser les cortines tales que tenirles en qualsevulla collegi o casa particular séria gran vergonya: hauem pensat que seria molt bona cosa y molt honrada fer venir huns bons draps de Flandes de la historia de la conquesta de aquest regne: notificam ho a v. m. vegen quels appar, y si li semblara hajam a fer dita prouisio, ho determenen", E. PASCUAL, Algo de los Libros de Determinacions del G. y G. Consell de la Universitat de Mallorca. Torres del temple: Orguens: Drap de ras: Abstinencia de carn, in BSAL 7, 1897-1898, p. 423.
} 
tropas de Jaime I de Aragón ${ }^{107}$. En este sentido, podemos interpretarlo como una muestra del orgullo cívico de la historia de la isla ${ }^{108}$, que si se hubiese llegado a realizar podría compararse con representaciones similares encargadas por corporaciones civiles en Europa.

El único fragmento de tapiz conocido hasta el momento se expone en el Museo de Mallorca (fig. 9) y procede de las colecciones de la Sociedad Arqueológica Luliana ${ }^{109}$. Se trata de una pieza realizada en talleres de Bruselas hacia 1500-1515 ${ }^{110}$, en muy mal estado de conservación y recortado. Representa tres personajes, el cen-

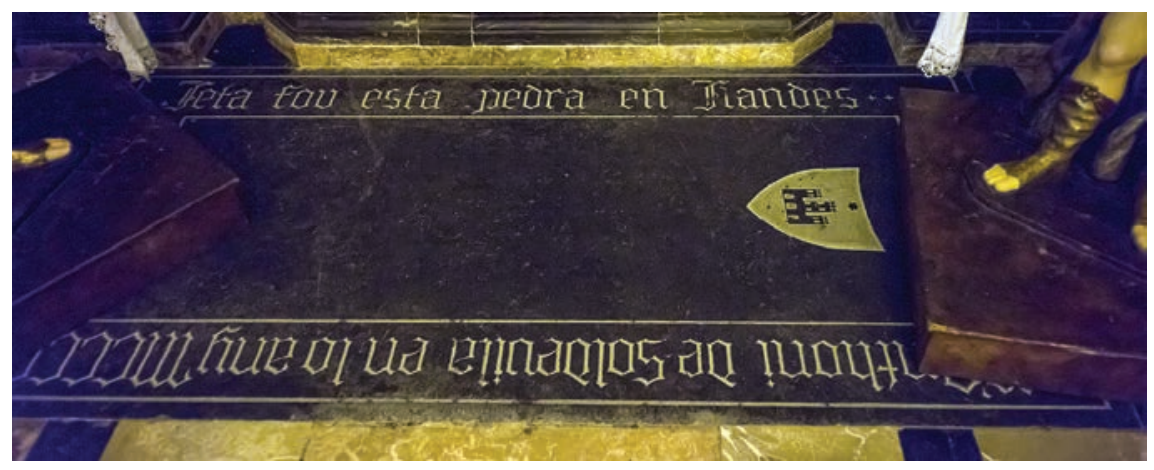
tral de frente, mientras que los laterales están en posición de tres cuartos, marcando una cierta simetría. Todos ellos muestran un semblante serio y con la mirada hacia abajo, el de la izquierda sostiene con las manos un libro cerrado, mientras que el personaje de la derecha lo tiene abierto. El fondo responde al tipo de tapiz de millefleurs, característico de estas producciones de finales del XV e inicios del XVI.

\section{A MODO DE CONCLUSIÓN}

La cultura material artística utilizada, disfrutada y visualizada en las casas en la Ciudad de Mallorca fue "rica y multiforme" y en parte por los objetos conservados, aunque la inmensa mayoría de ellos desaparecieron con los siglos por los cambios de moda. Como se ha comprobado a lo largo del artículo, en estos ambientes híbridos, también aparecen objetos producidos o comercializados desde Flandes, que ocupan un lugar preeminente en algunos ambientes al final del siglo XV.

Muchas de estas mercadurías artísticas se amoldaban a unos criterios estandarizados del gusto de un consumidor anónimo, que no buscaba innovaciones en las tipologías. A

pesar de estas limitaciones conceptuales y creativas, es indudable que estas piezas ayudaron a difundir entre individuos de estratos sociales diferentes los rasgos característicos de la cultura visual del período. Sin estudios más profundos y sistemáticos hasta el momento, se hace difícil intentar definir una sensibilidad estética propia de los mercaderes mallorquines, así como se ha intentado en otros ámbitos de la Corona de Aragón ${ }^{112}$. Aunque, sí existe algún ejemplo suficientemente significativo del orgullo de pertenecer a este estamento, como Antoni de Soldevila, mercader, que encargó una lápida sepulcral, con una placa de bronce desaparecida, en la que junto a sus armas, figura la inscripción (fig. 10): Feta fou esta pedra en Flandes per lo Honrat N’Anthoni Soldevila, en lo any MCCC, morí dit any ${ }^{113}$.

En este proceso de importación, los mercaderes jugaron un papel fundamental como intermediarios visuales al seleccionar objetos para sus clientes. Los miembros más destacados de este colectivo y en concreto aquellos que sirvieron el cargo como Jurados de la ciudad y reino de Mallorca, "la más alta representación del poder del Reino"114, ascendieron en la escala estamental, tendencia que se manifestó de forma clara en la segunda mitad del siglo XV. En estos casos parece claro que sus preferencias les aproximaron a los gustos de la nobleza.

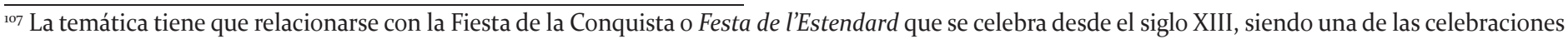
civiles más antiguas de Europa. Véase al respecto entre otros: G. LLOMPART, La Festa de l'Estandart [d'Aragó], una liturgia municipal europea en Mallorca (siglos XIII-XV), in Cuadernos de Historia Jerónimo Zurita 37-38, 1980, p. 7-34; A. I. ALOMAR, L’Estendard, la Festa nacional més antiga d'Europa, Palma, 1998.

${ }^{108}$ Esta incorporación de piezas de Flandes es testimonial si la comparamos con la colección que tenía la Generalitat de Valencia a finales del siglo XV, en S. ALDANA, op. cit. (n. 75), p. 30-31. En el caso de Barcelona, véase al respecto J. MOLINA I FIGUERAS, op. cit. (n. 103), p. 173-228.

${ }^{109}$ J. JUAN TOU, Tapiz gótico flamenco, in BSAL 37, 1979-1980, p. 442; M. À. CAPELLÀ GALMÉS, M. M. ESTARELLAS ORDINAS, J. MERINO SANTISTEBAN, La formació de les collleccions museològiques de la Societat Arqueològica Lul.liana, in La Societat Arqueològica Lul-liana, una il.lusió que perdura (1880-2003), Palma, 2003, p. 101-113.

${ }^{10}$ Museo de Mallorca, DA05/16/065. J. M. PALOU SAMPOL, Tapís, in Ceres. Colecciones en red <http: ceres.mcu.es> [Consulta: 15 octubre 2015].

"' J. V. GARCÍA MARSILLA, Mercados del lujo, mercados del arte, in S. BROUQUET, J. V. GARCÍA MARSILLA (ed.), Mercados del lujo, mercados del arte. El gusto de las elites mediterráneas en los siglos XIV y XV, València, 2015, p. 15.

${ }^{112} \mathrm{~J}$. AURELL, A. PUIGARNAU, Iconografia a les llars mercantils del segle XV. Mentalitat, estètica i religiositat dels mercaders a Barcelona, in Anuario de Estudios Medievales 25/1, 1995, p. 297-331.

${ }^{\text {"3 }}$ M. BARCELÓ CRESPÍ, B. COLL TOMÀS, G. ROSSELLÓ BORDOY, op. cit. (n. 17), p. 35-36.

${ }^{14}$ A. PLANAS ROSSELLÓ, op. cit. (n. 5o), p. 9, 153-154.
} 